\title{
WASHINGTON'S TEARS: SENTIMENTAL ANECDOTE AND WALT WHITMAN'S BATTLE OF LONG ISLAND
}

\author{
JASON STACY
}

Historian! you who celebrate bygones!

You have explored the outward,

[... $]$

But now I also, arriving, contribute something:

[... ]

I do not tell the usual facts, proved by records and documents,

What I tell, (talking to every born American,) requires no further proof than he or she who will hear me . . .

\section{"Chants Democratic" 10, Leaves of Grass (1860)}

Historians Frustrated Walt Whitman. ${ }^{1}$ Rather than proclaiming that the study of history would be remade in the New World's image-as he did with democracy, religion, and literature - the poet drew a wary line between himself and the historian. ${ }^{2}$ In the 1880 s, he imagined a new kind of historiography, but its practitioners proved distinct from the transformational literatus of Democratic Vistas: "I am waiting for the historians who will tell the truth . . . about the nobility of the people." ${ }^{3}$ When Whitman saw his own formative memories historicized in the late nineteenth century, he mused about saving them from facile historians: "I may perhaps be the only one living today who can throw an authentic sidelight upon the radicalism of those post-Revolutionary decades. The average historian has either not seen the facts at all or been afraid to do anything with them" (Traubel, 80). For Whitman, historiography followed literature as literature followed democracy. The poet hoped historians might eventually catch up or perhaps even prove themselves ultimately superfluous: "maybe goodness gets along on its own account without the historian" (Traubel, 157).

Nonetheless, Whitman imbued Leaves of Grass with historical thinking. The preface to the 1855 edition framed the poet's project in historical terms: the continents of the Old World "arrive[d] as contributions," and the bard "enclose[d] old and new" while simultaneously "see[ing] eternity less like a play with a prologue and denouement" than as the essence of men and women. When the bard called himself the "acme of things accomplished, and . . . an encloser of things to be," he embraced the rudimentary axioms of historical practice like cause 
and effect and change over time. ${ }^{5}$ This raises a perplexing question for the historian who takes an interest in Walt Whitman: how do both historicism and idealism function concurrently in Leaves of Grass? While it is possible to categorize this variance as one of Whitman's many selfcelebrated contradictions, a close reading of the poet's use of historical anecdote allows us to trace the way in which the poet came to use historicism in his writings. Specifically, Whitman employed the anecdote of Washington's defeat at the Battle of Long Island in his journalism from the mid-1840s and in the first and subsequent editions of Leaves of Grass to make consistent his claim that America's history was distinguished by its eternal nature. ${ }^{6}$ Washingtonian anecdotes about the Battle of Long Island proved useful to Whitman, who sought, first in his journalism, to move his fellow New Yorkers to enshrine the battle in their memory as the essential moment in the inexorable march to independence; and, later, in his poetry, to personify the contradictory idea that American history itself proved timeless and, therefore, exceptional.

\section{Washington and the Battles of Long Island}

Modern historians typically characterize Washington's defeat at the Battle of Long Island on August 27, 1776, and his retreat across the Hudson River into New Jersey as the beginning of the "times that $\operatorname{tr}[$ ied] men's souls" before the turning points of Saratoga (1777) and the alliance with the French (1778). ${ }^{7}$ One textbook calls this period "Struggling Toward Saratoga." Another characterizes the Battle of Long Island as a "terrible mistake" only rectified with the "important victory" at Saratoga. Another, riffing on modern popular culture, calls it Washington's "Escape from New York." ${ }^{\prime 8}$ While modern descriptions of the battle's significance characterize Washington's leadership as one of many elements that made this historical moment, all portray the battle as a point in a war narrative that began in crisis but turned and ended in American favor.

The origins of this narrative characterization of the Battle of Long Island lie in the first popular Revolutionary War histories. Unlike modern professional historical writing, these earliest histories of the battle depend almost exclusively on Washington's character and leadership; they are rich with anecdotal play and ethical imperatives and make history an object lesson in universal truths with Washington serving as the paragon of republican virtue and god-like steadfastness in the march to independence. ${ }^{9}$ Mason Locke Weems's $A$ History of the Life and Death, Virtues and Exploits of General George Washington (1800) initiated an industry of Washingtonalia that, according to one historian, has "sold more than any other single strand of historical writing in the United States." 10 
Weems's account of Washington's life proved less a history than a string of specious quotes tied together anecdotally into something like a narrative; the general strode from scene to scene, emulating contemporary ideals of poise and virtue in the face of British avarice and taught moral lessons from a distance, still rhetorically in the saddle and above the citizenry of the new republic. In this regard, Weems's biographies took their cues from classical models - especially Plutarch — and used historical moments to discover (or create) character-building object lessons useful for fulfilling contemporary standards of a virtuous citizenry; ${ }^{11}$ this evoked a kind of conservatism that established a means by which social and political questions could be answered through increasingly mythologized and hagiographical memories. ${ }^{12}$

With the rush of nationalism that followed the conclusion of the War of 1812, the passing of the revolutionary generation in the $1820 \mathrm{~s}$, the democratization of American political culture through the second and third decades of the nineteenth century, and the advent of the concept of Manifest Destiny that equated the spread of the American republic with the will of the cosmos in the $1840 \mathrm{~s},{ }^{13}$ hagiographical histories continued to enshrine Revolutionary War heroes, but changed from promoting moral lessons to purveying sentimental and emotive tales through which readers could recognize the general's sincerity. ${ }^{14}$ Karen Halttunen calls the culture of sentimentality a means by which middle class Americans "assigned value to private experience in proportion to its emotional intensity" whereby a "body's sympathetic response . . . [proved to be] the outward physical manifestations of the heart's contents." ${ }^{15}$ In this way, sentiment expressed an individual's inner life and true self.

In the sentimental historical anecdotes that appeared during this period, Washington's emotions became the mark of his humanity and, coupled with his super-human qualities, made him an ideal first-citizen for a sentimental era, capable of both great fortitude and great feeling, whose intense emotions proved the integrity of his actions. George Callcott argues that the filtering of Scottish Common Sense philosophy through American culture during the early decades of the nineteenth century fostered an infusion of sentimentality into the previous generation's hagiographical accounts to create a particularly American kind of romantic hero who exhibited greatness not through the sturm and drang of contemporary European models, but by an affinity for the people and through the exhibition of unaffected human sensibilities. ${ }^{16}$ Sentiment, both for and by a historic figure, proved to be the unassailable means by which the historian established a hero's intrinsic American superiority as simultaneously one of and one above the people, with an eminence tempered by common human feeling that equalized both the great and 
the common. Not surprisingly, Whitman's bard persona, whose egalitarian sensibilities fostered his bemused calm and all-seeing power, drew from contemporary discourses around the idea of a republican hero. ${ }^{17}$

The popularity of historical fiction during the early nineteenth century, especially that of Sir Walter Scott, also represented a shift in American historical writing that catered to the public's interest in humanized historical figures who nonetheless exhibited greatness. Between 1820 and 1840, thirty of the forty-two most popular historical works were fictional; books like James Fennimore Cooper's The Last of the Mohicans (1826) and other Leatherstocking Tales proved best sellers during this period (Calcott, 17). Cooper's Natty Bumppo exhibited the traits of a republican hero whose superiority lay in his ability to stay, literally and figuratively, close to the ground. When, in 1847, the editorialist and author George Lippard decried the previous generation's portrayal of Washington as a "figure of mist and frost . . . " he offered in return "the living, throbbing, flesh and blood, Washington!" whose emotive movements emulated fictional characters. ${ }^{18}$ This earthier, but still heroic, Washington, capable of feeling and human contradictions in the midst of historical drama, proved more compelling to a people whose self-proclaimed democratic and egalitarian spirit justified their conceptions of American exceptionalism.

The melding of middle-class sentimental culture and romantic historical fiction produced a new Washington. Jared Sparks, in The Life of George Washington (1839), portrayed a general whose emotional qualities allowed the reader to empathize with a steadfast and noble heart. A former chaplain of the House of Representatives, Sparks believed that no accurate history of the Revolution had been written since the war's end over fifty years before and spent a decade gathering sources for his twelve-volume The Writings of George Washington (1834), which allowed him to "understand the character of Washington . . . from his own writings." 19 According to Sparks, though the Battle of Long Island proved "disastrous to the Americans," it exemplified the general's best qualities. During his retreat from New York, which Sparks described as "one of the most remarkable military events in history," Washington, after having "witnessed the . . . slaughter of his troops with the keenest anguish," experienced an "anxiety . . . so unceasing . . . that for forty-eight hours he did not close his eyes, and rarely dismounted from his horse." In the aftermath, the general bore "with fortitude" the complaints of critics and, ultimately, refused to "suffer himself to be turned by them from what he believed to be his duty in watching over the vital interests of his country." 20 Over the course of this emotional trajectory, from anguish and anxiety to fortitude, Sparks's Washington proved both subject to human feeling and capable of extraordinary 
forbearance: "no trials . . . could depress the mind or unnerve the energy of Washington" (Sparks, 183).

Joel Tyler Headley's Washington and His Generals (1847), which Whitman reviewed positively in the Brooklyn Daily Eagle, ${ }^{21}$ likewise portrayed a sentimental Washington. As a protégé of Everett Duyckinck, publisher of the Library of American Books, a series dedicated to initiating an American literary tradition unfettered by Old World models, Headley echoed Young America's celebration of the nation's youthful vigor; his Washington grew from a young man of "strong and terrible passions," into a character of "cool and correct . . . judgment, quick impulses . . . [and] fearless [ness]" because "a warm and fiery heart is necessary for great resolution." 22 Thus, at the Battle of Long Island, while Washington's green volunteers fled before victorious British forces, the general, "astonished and indignant[,] . . . his lip curled in $\operatorname{scorn}[$,$] . . . wheeled and halted alone in front of the enemy, and$ there, like Murat before the Russian battery, stood and let the bullets whistle about him." Despite this impulsiveness, the general's "selfcontrol" proved master of his spiritedness: "the ingratitude and folly of those who should have been his allies ... never provoked him into a rash act, or . . . a single error" (Headley, 35-39). Like Sparks, Headley established Washington's repute by noting his "fortitude" in the face of contemporary criticism and thereby flattered his readers into a sense of knowing the real Washington better than the general's own contemporaries (Headley, 42).

But Washington's fortitude never became callousness. Popular historians utilized again and again an anecdote of Washington's anguished cry in the midst of the battle, "Good God! What brave fellows I must lose this day!" to exemplify the stormy passions beneath the general's stoic exterior. ${ }^{23}$ When faced with his retreating bedraggled army, the general became "overwhelmed with grief and despair[,] his manly features ... bathed with tears[,] . . . . the sternness of a soldier yielding to the softer feelings of a noble heart!" 24 Six years later, tears "freely bedew[ed] [Washington's] manly cheeks" as he embraced his decommissioned officers upon the final evacuation of the British from New York in $1783 .{ }^{25}$ Like his resilience in the face of popular criticism, Washington's tears bred a sense of familiarity with the general and awe at his emotional largesse in the midst of adversity and triumph.

\section{Signs of Agitated Passion}

George Washington and the Battle of Long Island provided the journalist Walt Whitman with a rich vein of sentimental anecdotes with which to editorialize on the times. The proximity of the battle 
site also allowed the future poet to compare and juxtapose the past and the present, ostensibly for his readers' edification and interest, but ultimately to make arguments regarding contemporary issues. In both the Sunday Times and the Brooklyn Daily Eagle, Whitman utilized sentimental accounts of Washington at Long Island to elicit the reader's connection with the general; while doing so, he established the means by which sentimental historical anecdote could prove the eternal nature of American democracy in Leaves of Grass.

Whitman's Washington and the Battle of Long Island first appeared in the Sunday Times in 1842 and allowed the future poet to gently critique the social and economic flux wrought by the new market economy while recounting "A Ramble of the Third Avenue" to "Kipp's Bay," the location of General Howe's landing in $1776 .{ }^{26}$ This represented one of the many journalistic rambles Whitman took through New York City during this period and, like most of these rhetorical strolls, followed a geographic trajectory whose significance was ostensibly left to the reader's interpretation. ${ }^{27}$ As Whitman moved "up Chatham street" he noted that it was appropriately named the "Old Jewry" because every shop was "occupied by a Pawn broker, or old clothes dealer." Above Pearl Street, the businesses turned to "Peter Funk shops," where "you can buy a watch for three cents and a thousand brass rings for the same price . . . . These fellows are worse than the Jews." ${ }^{28}$ At Broome Street, Whitman marveled at the spread of urban housing and the appearance of the railroad and noted that "twenty years ago . . . you could have stood on the eastern side of the Bowery . . . and obtained an unobstructed view of the east river over Stuyvesant's meadows . . . . [but] speculation has done something with all its evils." As Whitman left this newly urbanized space, he encountered two elm trees, "the last of their race," which formerly "fronted the entrance way" to the road that led to General Horatio Gates's mansion, now standing in a state of "complete dilapidation." ${ }^{29}$ Upon reaching Third Avenue, Whitman walked to Kip's Bay where a lone Dutch house stood as testament to the farms that once populated the area. ${ }^{30}$

The sight of the bay led to a rumination on the battle that took place near there sixty-six years before. Whitman related that as American troops retreated helter-skelter from British forces, Washington "immediately sprang on horseback" and, upon arrival at the scene, "was heard to use profane language [for the only time] during the revolution . . . 'd-----d scoundrels and cowards,' and at the same time pulled a pistol from his holsters, and threatened to shoot the first man that passed by him" (Fourn, 1:142). According to Whitman, Washington had to be pulled from the scene when the British were "within fifty yards of [him]" (Fourn, 1:142). This geographic narrative took the reader back 
in time for an ambivalent tour: from the city to the countryside, from the present to the past, through neighborhoods of recent immigrants, to Peter Funk's seedy side of the new market economy, to the imposition of the railroad and new housing onto the formerly pastoral landscape, past the remnants of colonial era homes to the scene of Washington's brave stand in the face of his first defeat. In Whitman's hands, Washington's legacy still chided America's retreat from a noble revolution, only this time his countrymen gave way to the blinkered progress of urban and economic growth.

In 1846, Whitman revisited the battle again, this time as part of the seventieth anniversary celebrations of the Declaration of Independence, and consistently worked throughout the remainder of the year to establish the Battle of Long Island as an essential moment in the American Revolution, worthy of commemoration by his fellow New Yorkers. His pitch began in the Daily Eagle on July 2, when he printed an "Ode: To be Sung on Fort Greene," by Walter Whitman, in which he called Washington the "Serene One ... faithful, . . . fearless ... . / Defending the worth, of the sanctified earth / We are standing on now." 31 This was followed the next day with a program of the day's events that warned readers not to "let the part which this section of Long-Island bears in the Revolution, be passed over in heedlessness." ${ }^{32}$ On the anniversary of the battle itself, Whitman appealed to his readers' sentiments in his call to commemorate the event:

Washington stood on our Island shores, and wrung his hands, while tears of the bitterest anguish gathered on his cheeks - sighs of agitated passion which he is said never to have given way to, or any other occasion, before or afterward! He found the 'Maryland regiment,' composed of young men - the flower of some of the finest families in the South-cut to atoms in that disastrous slaughter! . . . No wonder that, in that dreary hour, the soul of One elsetime as serene as a god's, felt sick within him. No wonder that his lips shed words of agony, bitter as blood-drops from a wounded heart. (Fourn, 2:34-35)

However, in the midst of defeat, Washington regained his composure and "set himself about . . . extricating his troops from the very clutches of a conquering enemy" (Fourn, 2:35). All of the hallmarks of the sentimental approach to historical anecdote were apparent here: a worried, weeping Washington, whose concerns were for the wellbeing of his soldiers, had his poise and fortitude tested in a moment of crisis that threatened to smother the Revolution in its infancy. Ultimately, the general's mettle proved true and he saved his army and, thereafter, his nation.

At the end of this article, Whitman's goal became clear, "And shall we not reserve at least one spot as a visible token of that sad and yet most 
glorious Day for America, and for human freedom?" (Fourn, 2:35). While Whitman lobbied for a memorial to the Battle of Long Island, he stepped gingerly around the fact that the battle proved disastrous for the Continental Army and caused many of Washington's contemporaries to question the general's competency. Other histories inoculated this unpleasant reality by noting that Washington's retreat showed his tactical genius (Sparks), that his bravery came to the fore in the face of a defeat he could not avoid (Headley), and that his intense and personally unprecedented emotional reaction to the slaughter- "Good God! What brave fellows I must lose this day!"-lent a sort of nobility to the defeat. Whitman incorporated these rhetorical strategies into his pitch for the building of a monument to the Battle of Long Island. Whereas many boosters justified a monument based on an event's place in the Revolution's narrative, ${ }^{33}$ or by the significance of the event that took place there, ${ }^{34}$ Whitman, taking his cue from contemporary histories, transformed the defeat at the Battle of Long Island into the first test of Washington's empathy and resilience; this sentimental justification allowed Whitman to trump all other monuments: Long Island tried George Washington's fabled fortitude and, in the midst of anxiety and grief, strengthened the moral fiber that eventually saved the Revolution. ${ }^{35}$ The general's "signs of agitated passion," never yielded to "before or afterward," became the evidence of the historical significance of the battle. Though technically a defeat for the infant United States, the battle ultimately represented the greatest victory of all. That Washington overcame his emotions and saved his army proved that the young republic had stronger moral fiber when tested against British might, thereby establishing the nation's victorious destiny at the moment of its greatest crisis.

\section{Forever Now}

Washington's only two appearances in the first edition of Leaves of Grass are at the Battle of Long Island and at the disbanding of the Continental Army in New York in 1783. Tucked within the poem that would eventually be called "The Sleepers," these anecdotes form the first part of three scenes that begin with the word "now," thus furthering Whitman's case for the mutability of time and an immediacy between the poet and the reader.

As in his journalism, the Battle of Long Island in Leaves of Grass becomes the historical moment that trumps better-known battles like Bunker Hill, Saratoga, and Yorktown (all of which are absent from the book) ${ }^{36}$ and begins with a familiar portrayal of Washington in the heat of the battle: 
Now of the old war-days . . the defeat at Brooklyn;

Washington stands inside the lines . . he stands on the entrenched hills amid a crowd of officers,

His face is cold and damp . . . he cannot repress the weeping drops . . . he lifts the glass perpetually to his eyes . . . the color is blanched from his cheeks,

He sees the slaughter of the southern braves confided to him by their parents.

$(L G 1855,73)$

Here is the well-known scene of Washington witnessing the destruction of Maryland volunteers before the British advance, but in a new form freed from the conventions of contemporary historical writing. In the previous scene, the poet collected the dead from a wrecked ship, which he watched helplessly as it sank into the winter sea; Whitman breaks this eye-witness account with an authoritative appeal to the present"now"- that sounds like the beginning of a didactic history lesson: "Now of the old war-days." However, though ostensibly a historical anecdote, Whitman tells the tale in the present tense, thereby heightening the sentimental effect: the reader is there with Washington and knows his heart first hand. Compared to Whitman's editorial of 1846, where Washington "stood on our Island shores . . . while tears of the bitterest anguish gathered on his cheeks," the poet bends time with tense in this case and achieves an effect Sparks and Headley attempted throughout the 1840 s. While antebellum historians used physical manifestations of Washington's emotions for realistic effect, Whitman brought the reader to Washington's side to witness his grief. Likewise, while it might seem a likely inference to say that the parents of the slaughtered Marylanders "confided" their children to Washington, it proves tenuous as a useful piece of historical information. In his Eagle editorial of 1846, these Marylanders came from the "finest families of the South," a sociological fact more appropriate to history's holistic stance. However, in Leaves of Grass this fact becomes thoroughly sentimental-parents of the young republic had confided their boys to Washington's care and now they would never return. Whitman's readers, then, as eyewitnesses, observe historical significance and intimate facts simultaneously, since both prove, ultimately, to be the same. Freed from the conventions of historical writing, yet still dependent upon a reader's familiarity with Washington, Whitman strips this historical anecdote to its emotive core and thereby locks Washington, his people, and the reader in a kind of sentimental union: standing by the general's side, the reader witnesses his greatest test where southern boys fell on northern soil for the sake of the new nation. Grief bound Washington to his people as it binds Whitman's readers to the general.

Washington at Long Island is followed by an anecdote of the Continental Army's disbandment in New York upon the close of the war: 
The same at last and at last when peace is declared,

He stands in the room of the old tavern .... the wellbeloved soldiers all pass through,

The officers speechless and slow draw near in their turns,

The chief encircles their necks with his arm and kisses them on the cheek, He kisses lightly the wet cheeks one after another . . . . he shakes hands and bids goodbye to the army. ( $L G 1855,74$ )

The "same" individuals who began the war together in defeat at Long Island in 1776 stand together at the "last" moment of the war, November 1783, once peace was declared "at last." Here, Washington's soldiers weep when he embraces them and kisses their wet faces. In these two anecdotes, bound together with tears, Whitman effectively begins and ends the American Revolution in New York and makes readers witnesses to Washington's suffering upon the nation's painful birth and his heartfelt farewell at the war's triumphant end.

We see in these two Washington scenes, then, examples of how, when Whitman applies his shape-changing voice and free-form verse to the past, he could eschew the conventions of contemporary historical writing while taking advantage of a sentimental anecdote's ability to explore the inner lives of historical actors and elicit emotional responses from readers. Whitman's sentimental anecdotes therefore give readers license to stand with the general at the dire beginning of the American Revolution and to attend the tearful farewell at its victorious end. This makes porous the barriers between the past and the present: Washington fights for freedom in the present tense. Toward the end of his life, when Whitman dreamed that perhaps history would catch up to his brand of revolutionary literature, he really imagined an end to historical writing itself. History becomes poetry without the conventions that make it somewhat stolid. While antebellum historians pushed to the margins of this stolidity in their attempt to depict Washington's inner life, Whitman, in his quest to portray America's past, present, and future in a little book that eternally spoke to the "now," ultimately could not wait for them.

Southern Illinois University Edwardsville 


\section{NOTES}

1 Many scholars have analyzed Whitman's political and social views with an eye to his historical context. See M. Wynn Thomas, The Lunar Light of Whitman's Poetry, (Cambridge, Mass: Harvard University Press, 1987); Betsy Erkkila, Whitman the Political Poet (New York: Oxford University Press, 1989); James Dougherty, Walt Whitman and the Citizen's Eye (Baton Rouge: Louisiana State University Press, 1993); Luke Mancuso, The Strange Sad War Revolving: Walt Whitman, Reconstruction, and the Emergence of Black Citizenship, 1865-1876 (Columbia, SC: Camden House, 1997); Jay Grossman, Reconstituting the American Renaissance: Emerson, Whitman, and the Politics of Representation (Durham: Duke University Press, 2003); Andrew Lawson, Walt Whitman $\mathcal{E}$ the Class Struggle (Iowa City: University of Iowa Press, 2006).

2 "Chants Democratic" 10 was re-titled "To A Historian" in the 1867 edition of Leaves of Grass.

3 Horace Traubel, With Walt Whitman in Camden (Various Publishers, 1806-1996), $1: 157$.

4 Whitman, Leaves of Grass, 1855, iii-v. Hereafter, LG 1855. Available on the Walt Whitman Archive (www.whitmanarchive.org).

5 Whitman, Leaves of Grass, 1860, 93. Hereafter, LG 1860. Available on the Walt Whitman Archive (www.whitmanarchive.org).

6 For Whitman's philosophy of history and the influence of Hegel upon it, see John W. McDonald, Walt Whitman, Philosopher Poet: Leaves of Grass by Indirection (Jefferson, NC: McFarland \& Co, 2007), 91-100. According to McDonald (94), Whitman's “To Thee, Old Cause!" (1872), represents the poet's Americanized version of the Hegelian Geist that existed within time while simultaneously transcending and shaping temporal context: "To thee, old Cause! / Thou peerless, passionate, good cause! / Thou stern, remorseless, sweet Idea! / Deathless throughout the ages, races, lands! / After a strange, sad war-great war for thee, / (I think all war through time was really fought, and ever will be really fought, for thee;) / These chants for thee-the eternal march of thee."

7 “These are the times that try men's souls," Thomas Paine, The Crisis, 1776. In 1777, the American forces of General Horatio Gates successfully forced the surrender of General John Burgoyne in upstate New York at the Battle of Saratoga, which led to an alliance with France in January 1778. The French diverted British attention and supplies from the North American rebellion and provided an essential naval blockade of General Charles Cornwallis's forces at the Battle of Yorktown (1781).

8 Gerald A. Danzer, et al., The Americans, (Evanston, IL: McDougal Littell, 2007), 113; Gary Nash and Julie Roy Jeffrey, The American People: Creating a Nation and a Society (New York: Pearson/Longman, 2006), 192; Carol Berkin et al., Making America: A History of the United States (New York: Houghton Mifflin Company, 2006), 155-156. Escape from New York, a dystopian adventure film starring Kurt Russell, was released in 1981.

9 Mercy Otis Warren's History of the Rise, Progress and Termination of the American Revolution: Biographical Political and Moral Observations (Boston: Manning and Loring, 1805) proved a notable exception when it gently criticized Washington's actions on Long Island by calling his occupation rather "incautious" as the island contained "many settlements ... principally [of] loyalists" and implying that Washington's escape was due more to British General Howe's errors than to Washington's military 
acumen (1:317). See Nancy Rubin Stuart, The Muse of the Revolution: The Secret Pen of Mercy Otis Warren and the Founding of a Nation (Boston: Beacon Press, 2008).

10 Michael Kammen, A Season of Youth: The American Revolution and the Historical Imagination (New York: Cornell University Press, 1978), 41.

11 See George Callcott, History in the United States 1800-1860: Its Practice and Purpose (Baltimore, MD: The Johns Hopkins Press, 1970), 14; Michael Kammen, Mystic Chords of Memory: The Transformation of Tradition in American Culture (New York: Alfred A. Knopf, 1991), 65.

12 These popular memories, in turn, drew upon eighteenth-century English constitutional debates whereby Whiggish politicians and intellectuals justified arguments for individual rights and mixed governance with conceptions of an ancient, organic constitution whose origins lay in England's quasi-mythic founding by freedom-loving Anglo-Saxon tribesmen. In this regard, an essential source is still Bernard Bailyn, The Ideological Origins of the American Revolution (Cambridge, Mass: The Belknap Press of Harvard University Press, 1967), 33-54, 80-81.

13 See Charles Grier Sellers, The Market Revolution: Facksonian America, 1815-1846 (New York: Oxford University Press, 1991); Edward L. Widmer, Young America: The Flowering of Democracy in New York City (New York: Oxford University Press, 1999); Sean Wilentz, The Rise of American Democracy: Fefferson to Lincoln (New York: Norton, 2005); Daniel Walker Howe, What Hath God Wrought: The Transformation of America, 1815-1848 (New York: Oxford University Press, 2007).

14 For descriptions of phases of early American historiography, see $A$ Season of Youth: The American Revolution and the Historical Imagination, especially 41-59, and Callcott, 6-72.

15 Karen Halttunen, Confidence Men and Painted Women: A Study of Middle-Class Culture in America, 1830-1870 (New Haven: Yale University Press, 1982), 57.

16 Callcott, 17. For the ever-present fear of frauds and hypocrites bred by this cult of sentiment, see Halttunen, 33-56. Also see Philip Gould, "Remembering Metacom: Historical Writing and the Cultures of Masculinity in Early Republican America," in Mary Chapman, Sentimental Men: Masculinity and the Politics of Affect in American Culture. (Berkeley: University of California Press, 1999), 112-125.

17 "Of all mankind the great poet is the equable man . . . . [H] e does not see men and women as dreams or dots." (LG 1855, iv-v). See Andrew Lawson, Walt Whitman and the Class Struggle (Iowa City: University of Iowa Press, 2006); Jason Stacy, Walt Whitman's Multitudes: Labor Reform and Persona in Whitman's fournalism and the First Leaves of Grass, 1840-1855 (New York: Peter Lang Publishing, 2008); M. Wynn Thomas, The Lunar Light of Whitman's Poetry (Cambridge, Mass: Harvard University Press, 1987).

18 George Lippard, Washington and his Generals: or, Legends of the Revolution (Philadelphia: T.B. Peterson, 1847), 107; for Lippard's brand of Gothic-inflected, reformminded historical writing, see David Reynolds, George Lippard (Boston: Twayne Publishers, 1982), 49-72.

19 Kammen, A Season of Youth, 47-48; 52; George Washington, The Writings of George Washington, ed. Jared Sparks (Boston: American Stationers' Co, 1834), iv.

20 Jared Sparks, The Life of George Washington (London: Henry Colburn, 1839), $1: 192-194$. 
21 Walt Whitman, The fournalism, 1846-48, ed. Herbert Bergman, Douglas A. Noverr, Edward J. Recchia (New York: Peter Lang, 2003), 2:268. Hereafter, fourn 2.

22 Widmer, 148-149. Young America proponents encompassed interests ranging from literary nationalism, westward expansion, and free-trade economics. Nominally sympathetic to the Democratic Party, Young America's advocates proved generally urban, northeastern, and born in the first decades of the nineteenth century. Young America's best-known spokesperson, John O'Sullivan, edited the Democratic Review and coined the term "Manifest Destiny." See Edward L. Widmer, Young America: The Flowering of Democracy in New York City (New York: Oxford University Press, 1999), 3-26. Joel Tyler Headley, Washington and his Generals (New York: Charles Scribner, 1854), 28-29.

23 Typically ascribed to an "annonymous rifleman" this quote's popularity rose as sentimental anecdotes grew in popularity throughout the 1840 s and 1850 s. For examples of the various and diverse forums where the quote appeared, see Annals of Annapolis, ed. David Ridgely (Baltimore: Cushing \& Brother, 1841), 185; review of History of Maryland, from its First Settlement in 1634 to the Year 1848, in The Literary World: A fournal of American and Foreign Literature, Science and Art (March 17, 1849), 245, col. 3; Washington Irving, Life of George Washington: Volume 2 (New York: G.P. Putnam, 1856, quote found in the 1885 edition of vol. 2), 347; T. Addison Richards, Appletons' Illustrated Hand-Book of American Travel (New York: D. Appleton, 1857), 173; Jacob Harris Patton, The History of the United States of America (New York: D. Appleton, 1859), 376; E. Cecil, Life of George Washington: Written for Children (Boston: Crosby, Nichols, and Company, 1859), 102.

24 Hazard's United States Commercial and Statistical Register, ed. Samuel Hazard (Philadelphia: William F. Geddes, 1840), 3:220.

25 Richard Hildreth, The History of the United States of America (New York: Harper \& Bros, 1849), 3:441.

26 Walt Whitman, The fournalism, 1834-1846, ed. Herbert Bergman, Douglas A. Noverr, and Edward J. Recchia (New York: Peter Lang, 1998), 1:140-142. Hereafter, fourn 1.

27 For similar "rambles" or "peeps," see fourn, 1:52-57; 60-61; 66-67; 75-77; 83$84 ; 115-116$.

28 Peter Funk, a character in Asa Green's The Perils of Pearl Street (1834), became a common moniker for a kind of grifter in the 1840s. See Louise Pound, "Peter Funk: The Pedigree of a Westernism," American Speech (February 1929), 183-186. Whitman also used a Peter Funk character in an article entitled "Peter Funk, Esq." (Daily Crescent, March 13, 1848), where Funk played a shill in a fraudulent watch auction. See The Uncollected Poetry and Prose of Walt Whitman, ed. Emory Holloway (Gloucester, Mass: Peter Smith, 1972) 1:199.

29 Whitman called Gates the "hero of Saratoga" in this article, but his readers might also have recalled that Gates showed some support for the Newburgh conspirators, a disgruntled group of Washington's officers who plotted to force a coup d'etat (or something quite close to it) in 1783 . Washington ultimately quashed the plot before it came to fruition. See Richard H. Kohn, "The Inside History of the Newburgh Conspiracy: America and the Coup d'Etat," William and Mary Quarterly 27 (April 1970), 188-220. According to Kohn, "Fed by disillusionment, frustration, and personal dreams of glory, Gates and his young zealots evidently lost all sense of reality and began planning a full-fledged coup d'etat" (200). 
30 Originally owned by Jacob Kip, the house in the form that Whitman found it stood from 1696 to 1851. See Schuyler Van Rensselaer, History of the City of New York in the Seventeenth Century (New York: The Macmillan Company, 1909), 71.

31 Available on the Walt Whitman Archive (www.whitmanarchive.org).

32 “City Intelligence. The Celebration To-morrow!” Brooklyn Daily Eagle (July 3, 1846). Available on the Brooklyn Public Library's Brooklyn Daily Eagle Online, 18411902 (eagle.brooklynpubliclibrary.org).

33 The monument at Bunker Hill was completed in 1843.

34 A monument to the Siege of Yorktown was erected in 1881.

35 Throughout 1846 and into 1847 Whitman continued to portray Washington in sentimental terms and celebrate major events of the Revolution that took place in New York. See Fourn, 2:132-133; 138-139; 204; 265-266.

36 In the poem that became "Song of Myself," Whitman poeticized an anecdote of the Battle of Flamborough Head, which took place on September 23, 1779, between the U.S. Bonhomme Richard and the H.M.S. Serapis. 